\title{
Development planning to accelerate Sustainable Development Goals (SDGs) in Mahakam Ulu District as a new autonomous region
}

\section{Perencanaan pembangunan untuk percepatan Tujuan Pembangunan Berkelanjutan (SDGs) di Kabupaten Mahakam Ulu sebagai daerah otonomi baru}

\author{
Bambang Irawan ${ }^{*}$, Paisal Akbar ${ }^{2}$, Eko Priyo Purnomo², \& Achmad Nurmandi ${ }^{2}$ \\ ${ }^{1}$ Department of Master Public Administration, Faculty of Social and Political Sciences, \\ Universitas Mulawarman \\ ${ }^{2}$ Department of Government Affairs and Administration, Jusuf Kalla School of Government, \\ Universitas Muhammadiyah Yogyakarta \\ Address: ${ }^{1}$ Jalan Kuaro, Gunung Kelua, Samarinda Ulu, East Kalimantan, Indonesia 75119 \\ ${ }^{2}$ Jalan Brawijaya, Kasihan, Bantul, Special Region of Yogyakarta, Indonesia 55183 \\ E-mail: bambangirawan@unmul.ac.id
}

Article History: Received 19 May 2020; Accepted 14 March 2021; Published Online 19 April 2021

\begin{abstract}
The new autonomous regions have been seen as a burden because many have not developed into areas that can build inclusive societies. The upstream area of the Mahakam River in 2013 bring forth a new autonomous region called the Mahakam Ulu District, and the study aims to describe development planning in the region. This research adopt a descriptive qualitative approach using secondary data. The research results show that the newly autonomous region of Mahakam Ulu District is a breath of fresh air for the people of the ideals of equitable development in their regions. Development planning has also upheld the SDGs' goals, this can be seen from the programs that have been carried out, aiming to bring the Mahakam Ulu District prosperity and justice. The transformation of the values contained in the pillars of the SDGs has also felt to be present in the annual priority programs that have been carried out by Mahakam Ulu District, including in terms of social development, environmental development, economic development, and legal and governance development which continue to be pursued by all parties upstream of the Mahakam River, Mahakam Ulu District.
\end{abstract}

Keywords: development planning; inclusive communities; new autonomous region; SDGs

\begin{abstract}
Abstrak
Daerah otonomi baru selama ini cenderung dipandang sebagai beban karena banyak yang tidak mampu mengembangkan wilayahnya menjadi daerah yang dapat membangun masyarakat yang inklusif. Wilayah hulu Sungai Mahakam pada tahun 2013 melahirkan sebuah daerah otonomi baru, yaitu Kabupaten Mahakam Ulu dan studi ini bertujuan untuk mendeskripsikan perencanaan pembangunan di daerah tersebut. Penelitian ini menggunakan metode pendekatan kualitatif. Hasil peneltian menunjukkan kehadiran daerah otonomi baru Kabupaten Mahakam Ulu menjadi angin segar bagi masyarakat atas cita-cita pemerataan pembangunan di wilayahnya. Perencanaan pembangunan pun telah menjunjung tinggi pencapaian tujuan-tujuan pembangunan berkelanjutan, hal ini dapat dilihat dari program-program yang telah dijalankan dimana bertujuan untuk menghadirkan Kabupaten Mahakam Ulu yang memiliki kesejahteraan dan berkeadilan. Transformasi nilainilai yang terkandung di dalam pilar-pilar tujuan pembangunan berkelanjutan juga sudah terasa hadir di dalam program-program prioritas tahunan yang telah dijalankan Kabupaten Mahakam Ulu di antaranya dalam sisi pembangunan sosial, pembangunan lingkungan, pembangunan ekonomi, dan pembangunan hukum dan tata kelola yang terlihat terus diupayakan kehadirannya oleh semua pihak di hulu Sungai Mahakam Kabupaten Mahakam Ulu.
\end{abstract}

Kata kunci: perencanaan pembangunan; komunitas inklusif; daerah otonom baru; SDGs

\section{Introduction}

Mahakam River is the longest river in East Kalimantan Province, stretching along $920 \mathrm{~km}$ with 149.277 $\mathrm{km}^{2}$ across several districts or cities, including Samarinda City, Kutai Kartanegara Districts, West Kutai Districts, and Mahakam Ulu District. In each flow, the Mahakam River throbs with the economic pulse 
for the people living on the coast (Aisyah et al. 2008, Dishub Kutai Kartanegara 2021, Indonesia-info. net 2021). Geographically, the most upstream point of the Mahakam River is currently in the Mahakam Ulu District, and the downstream point is in Samarinda City (Indonesia Kaya 2019). On 20 May 2013, a new districts formed in the uppermost region of Mahakam River named Mahakam Ulu District under Law Number 2 of 2013. Mahakam Ulu has five sub-districts, namely Long Hubung, Laham, Long Bagun, Long Pahangai, and Long Apari. Each of these sub-districts has a village area that, if added up by the Mahakam Ulu District, has 50 villages (Badan Pusat Statistik Kabupaten Kutai Barat 2019).

As a new autonomous region, these five sub-districts have unfavorable conditions than sub-districts in the central district and sub-districts in other districts or cities in East Kalimantan Province. It is motivated the desire of five districts to become a new autonomous region in order to accelerate the realization of regional progress through increasing development both at the level of public service development, economic sector development, the construction of education and health facilities, and fulfilling the rights of political participation of the community to realize prosperity in the area (Pemerintah Provinsi Kalimantan Timur 2013, Muqoyyidin 2013).

The regional autonomy policy exists to give the region authority to realize equality, provide political education and democracy, provide efficiency in public services, increase the region's acceleration, and realize good governance (Kadaryanto 2017, Moonti 2019). Regional expansion is one of the enforcement forms of regional autonomy that must be a concern in its implementation. The spirit built- in splitting the region is the desire to progress toward the region's people (Muqoyyidin 2013, Yakub et al. 2018). The presence of a new autonomous region always has positive and negative impacts (Akbar 2018). The birth of a new autonomous region expects to increase community participation in developing the region. On the other hand, regional autonomy itself cannot be separated from the local elite's interests to master all existing resources in the new autonomous region.

In developing a new autonomous region, careful planning is needed and considers all strategic aspects, which are the basis for the success or failure of regional autonomy. Therefore, the right strategy is needed to manage government policies that support the new autonomy region (Darlen et al. 2015, Moonti 2019). The new autonomous region experienced poor development prospects because institutional arrangements did not go well; the resulting impact on regional development policy products' output did not show results (Wismono et al. 2015). Several activity sectors that can make a positive contribution to economic development and the development of local competitiveness and as a source of excellence in regional competitiveness in the economic sector the development sector, then followed by the agriculture sector, the health sector, and other service sectors (Sugino 2010, Wenda \& Akib 2015, Yuniza 2014).

In establishing new regional autonomy, the aim is to improve the community's welfare, accelerate development, and increase access to quality public services (Moonti 2019, Sulistiowati 2014). Sulistiowati (2014) argued that there were differences in carrying out the local government's four functions: public service, policymaking, service management, and community empowerment. It shows the government's seriousness in advancing the region must always be used as a basis for the government to function as it should (Sulistiowati 2014). According to Jati (2012), two essential things become a concern when discussing regional autonomy in Indonesia; 1) the uncertainty in determining the basic paradigm between decentralization or centralization in carrying out regional autonomy policy and 2) regional autonomy has led to the ruling regimes in the regions, which later crystallized into local political oligarchies, which became a political dynasty - related to the effectiveness of regional autonomy in Indonesia. Prabowo (2019) stated that regional autonomy must be accompanied by solid development policies and supervision to achieve regional development's effectiveness to the maximum. Mi'rojul (2017) stated that public satisfaction is a way to measure service implementation success in implementing regional autonomy in the South Tangerang region, where ten out of fourteen service elements have shown improvement in new autonomy areas, specifically within existing health services. What happened in South Tangerang shows that the autonomous region has become a way to advance various kinds of service functions at the regional level to be better in the future (Purnamasari 2015). 
The implementation of regional autonomy is inseparable from its role in achieving social welfare in the region. Badrudin and Siregar (2015) show that regional autonomy has a maximum effect on economic growth spending but, ironically, does not significantly influence community welfare. The new autonomous regional government must realize prosperity for the people supported by sound economic development management. It is realized by development at the most basic level, namely village development, based on the leadership concept built in the village to produce policies that can improve the community's welfare (Agustina 2019).

In Law 23 of 2014, there was a change and readjustment from the previous law concerning the expansion and formation of new autonomous regions. The autonomous region that wants to be divided must first pass the feasibility test as a preparation area to be expanded later (Kadaryanto 2017). Moreover, if the region can fulfill the stipulated conditions in the preparation period, it will be approved as a new autonomous region. If the region cannot meet the requirements, the status will be reviewed and returned under the districts or city. In its implementation, an autonomous region's formation does not always experience success; many new autonomous regions have difficulty carrying out their regions' development and development. It is because it is still absent in presenting the core of decentralization that should bring government closer to the people and the immaturity of planning in determining regional strategic resources that can support original local revenue to enhance the development of the new autonomous region (Simanjuntak 2015, Warsono \& Yuwanto 2016).

An inclusive society is the embodiment of all the community's social justice components to present a better life quality. Walker \& Musti-Rao (2016) see an inclusive society as an effort to build a society that gives concern to people who have limitations based on the assessment that every human being has the same rights and dignity. United Nations Educational, Scientific and Cultural Organization (UNESCO) defines an inclusive society as a society that presents access to the involvement of all components of society by affording equal opportunities for all things, and the same ability in order to establish rules that will later become the foundation in the process of the community's social interaction (United Nations Development Programme 2011).

Development in various fields of life is needed in the areas of access to education, access to health, economic equality, increased social awareness, and political participation in creating an inclusive urban society (Beckett 2009, Gea et al. 2016, Pelle \& Laczi 2015, Walker \& Musti-Rao 2016). Maftuhin (2017) stated that in Indonesia, many cities make "inclusive cities" as a goal of development that the city will run; however, in reality, these cities do not yet have an established concept. In their implementation, they have still not comprehensively achieved what is required to be an inclusive city. The implementation of inclusive cities in Indonesia is mainly focused on access to inclusive education and disabled-friendly public facilities (Ariastuti \& Herawati 2016, Darma \& Rusyidi 2015, Maftuhin 2017). The obstacles faced by cities in Indonesia to create an inclusive society include the social conditions of people who do not have full awareness of equal rights, regulations on government regulations that are not yet comprehensively available, involvement in the formulation of policies that do not yet exist, and availability in fulfilling the fundamental rights of the impoverished community (Maftuhin 2017, Walker \& Musti-Rao 2016, Zhao \& Zhang 2018).

Sustainable Development Goals (SDGs) resulted from the open working group's formulation formed by the United Nations General Assembly. The open working group proposed a set of SDGs consisting of 17 goals and 169 achievement targets (Fukuda-Parr 2016). Fukuda-Parr (2016) revealed that people had gone through the Millennium Development Goals (MDGs) era before the SDGs era; however, SDGs were different from MDGs in terms of goals, concepts, and politics. The differences in this are related to the number of goals and targets to achieve and speak in their different political goals, conceptions, and processes to encourage different technical descriptions. In the SDGs, the goals contain a variety of interconnected interactions between one goal and another; in a sense, to achieve one of the 17 SDGs goals, there is a need to pay attention to other objectives where the goal indicators are interconnected with each other (Le Blanc 2015). Therefore, in the case of the development of various fields of life 
in an area toward an inclusive society, it must adapt to the SDGs, which, in its implementation, have the four pillars of social development, environmental development, economic development, and legal development and governance (Kementerian Perencanaan Pembangunan Nasional 2020).

To realize all kinds of final objectives of the regional autonomy, the seriousness, and commitment of the new autonomous regional government of Mahakam Ulu, which is just entering its seventh year, are needed to realize an inclusive society. Based on this reason, this research aimed at measuring how far the newly autonomous region of Mahakam Ulu can bring about the presence of an inclusive society that is realized by upholding the principles of SDGs in the area. The study aims to describe development planning in the newly autonomous region of Mahakam Ulu as an inclusive society.

\section{Research Method}

This study uses qualitative research methods with a descriptive approach. Descriptive qualitative research is intended to understand what is happening in the field experienced by research subjects by describing a series of words and language by utilizing various natural methods (Moleong 2007). Mahakam Ulu District was chosen as a research area because it is the youngest in East Kalimantan Province and is still a new autonomous region, which is only seven years old. Besides that, geographically, the Mahakam Ulu is located at the upper end of the Mahakam River and borders directly with Malaysia's state (Badan Pusat Statistik Kabupaten Kutai Barat 2017, Indonesia Kaya 2019). For several reasons, the researchers considers Mahakam Ulu to be a suitable subject to see how far the new autonomous region can realize inclusive communities in the region upstream of the Mahakam River.

This study uses secondary data collection methods obtained from literature studies through data obtained from previous scientific research articles, online news media, social media, and related websites supporting literature study data collection (Posumah 2015). Social media data are processed using the Qualitative Data Software Analysis (QDSA) NVivo 12 Plus, which helps an analytical tool that can read the text and the qualitative data content (Brandão 2015, Kaefer et al. 2015). In this emphasis, this research is interpretive and emphasizes the interpretation of social phenomena, meaning to study specific views about the research subjects studied (Fithriana \& Annissa 2016, Miles \& Huberman 2009, Purwaningsih 2015).

\section{Results and Discussion}

\section{Mahakam Ulu District}

Mahakam Ulu is the autonomous region with the youngest age in East Kalimantan Province (Figure 1), with the district's capital located in Ujoh Bilang (Badan Pusat Statistik Kabupaten Kutai Barat 2017). Badan Pusat Statistik Kabupaten Kutai Barat (2019) explained that the Mahakam Ulu has five districts, with the percentage of district area as follows 1) Laham 5.89\%, 2) Long Hubung 3.47\%, 3) Long Bagun $32.46 \%$, 4) Long Pahangai $22.33 \%$, and 5) Long Apari 35.85\%. The distance between sub-districts to the district's capital cannot be said to be close. It calculated that the closest distance to reach $56 \mathrm{~km}$, namely Laham, while the farthest distance from the district capital is the Long Apari with a distance of $335 \mathrm{~km}$; both sub-districts could only be accessed using a route river crossings using speedboats because there is no access between the sub-district highway to the capital of the districts (Badan Pusat Statistik Kabupaten Kutai Barat 2020a). The Mahakam Ulu area reaches $15.315 \mathrm{~km} 2$, with rough topography and sloping to the steep slope of $0-60 \%$. The location of the Mahakam Ulu is at an altitude above sea level, reaching 1.500 masl, this districts' low-lying area is generally located along the watershed area (Badan Pusat Statistik Kabupaten Kutai Barat 2019, 2020b).

The population in an area constantly changes due to fertility, mortality, and migration. These factors determine the level of population growth. In its development, Mahakam Ulu has increased every year in terms of population (Table 1). Table 1 shows that the population growth of Mahakam Ulu from 2014 to 
2019 has always tended to increase in population. Table 1 shows that in 2017 the population increased significantly compared to the total population in 2016. It is in addition to the condition of essential service quality in terms of recording population growth, also accompanied by the opening of new opportunities in entrepreneurship and creative economy that are supported in the Regional Development Work Plan or Rencana Kerja Pembangunan Daerah (RKPD) of Mahakam Ulu, so that community mobilization to settle in Mahakam Ulu is increasing (Bappelitbangda 2018).

Table 1.

Total population of Mahakam Ulu

\begin{tabular}{lllllll}
\hline Description & $\mathbf{2 0 1 4}$ & $\mathbf{2 0 1 5}$ & $\mathbf{2 0 1 6}$ & $\mathbf{2 0 1 7}$ & $\mathbf{2 0 1 8}$ & $\mathbf{2 0 1 9}$ \\
\hline Total population & 25.894 & 25.970 & 26.089 & 26.305 & 26.347 & 26.375 \\
Gender ratio & 113.52 & 114.36 & 114.67 & 113.60 & 113.68 & 114.25 \\
\hline
\end{tabular}

Source: Badan Pusat Statistik Kabupaten Kutai Barat (2019, 2020a)

On the other hand, the new autonomous region of Mahakam Ulu requires a large composition of the State Civil Apparatus or Aparatur Sipil Negara (ASN) to fill out the formations in the offices and agencies in the Mahakam Ulu, and 2018 Mahakam Ulu opened the formation. It also became an attraction for the community to look for Mahakam Ulu opportunities and caused an increase in population. Figure 2 shows the highest percentage of Mahakam Ulu's population in the area of Long Bagun, with the percentage of population reaching $44.46 \%$ of the total population in Mahakam Ulu. The smallest percentage of the population is 7.69\%, or around 2.029 people (Badan Pusat Statistik Kabupaten Kutai Barat 2020b).

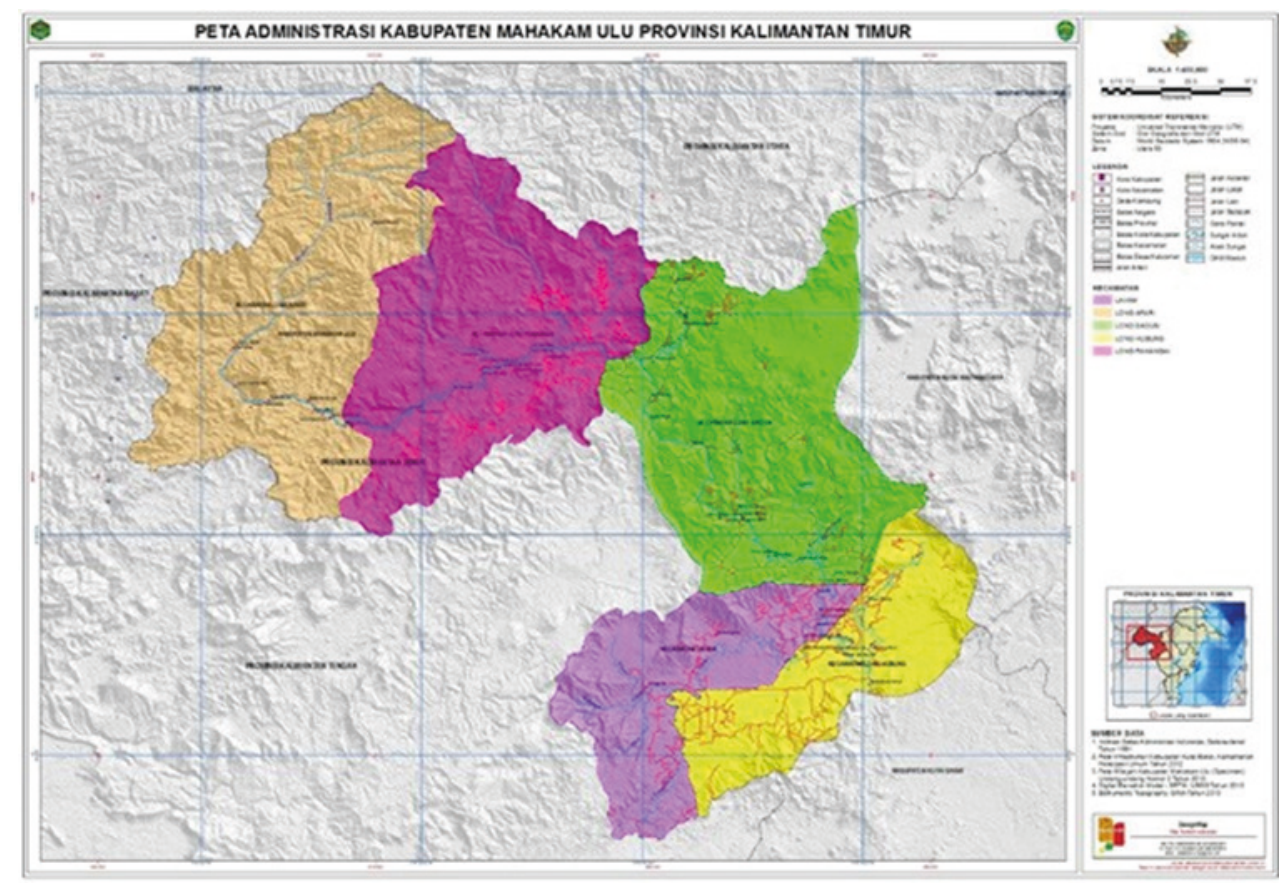

Figure 1.

The map of Mahakam Ulu District

Source: Peta Tematik Indonesia (2014)

\section{Inclusive community development in Mahakam Ulu District}

An inclusive society is an effort to realize the condition of a society that actively gives care to people who have limitations. This concern is realized based on the understanding that every human being has the same rights and dignity (Walker \& Musti-Rao 2016). To categorize an inclusive society Maftuhin (2017) tries to provide four indicators of the realization of an inclusive city, which can then present an inclusive society; first, full participation, which in this case wants the involvement of those definable as can actively participate in all aspects of life as a citizen of the city. Second, the availability of rights services 
is realized by providing services, facilities, programs, or buildings to fulfill the rights of persons with disabilities following those stipulated in the regulations. Third, accessibility means making it easy for the disabled or other society members to benefit from a facility, service, building, and program. Fourth, an inclusive attitude means the government's attitude and the general public who understand to avoid discriminatory attitudes, provide fulfillment, protection, and respect the rights of other communities, especially persons with disabilities.

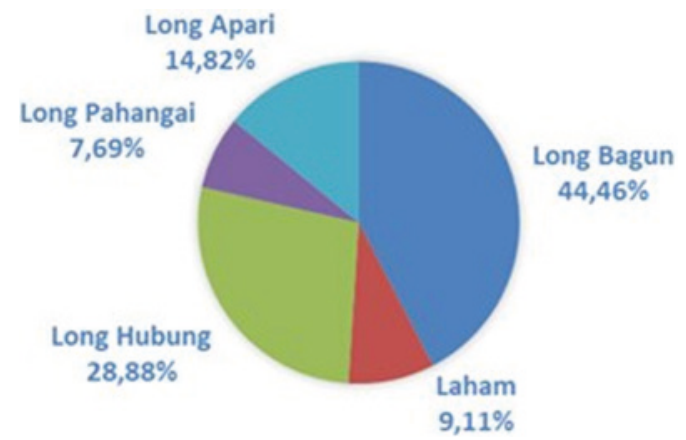

Figure 2.

Population distribution of Mahakam Ulu District Source: Badan Pusat Statistik Kabupaten Kutai Barat (2019, 2020b)

Mahakam Ulu is a new autonomous region that is significantly behind compared to other districts or city areas in East Kalimantan Province. In the implementation toward inclusive community, Mahakam Ulu has stated it in the stages of the Mahakam Ulu Long Term Development Plan (hereafter called RPJPD) for 2016-2025; the RPJPD has the objectives set out in the RPJPD vision of Mahakam Ulu, namely, the realization of the Mahakam Ulu as a border area prosperous, environmentally based, natural resource-based and local wisdom (Bappelitbangda 2018). As a new autonomous region, it is certainly not easy to realize it. The vision of the RPJPD then transformed into the objectives of the 2016-2021 Regional Medium-Term Development Plan I (RPJMD-I) with the vision of building Mahakam Ulu for all: prosperous justice (Bappelitbangda 2018). Badan Perencanaan Pembangunan, Penelitian dan Pengembangan Daerah (2018) explained that, in the RPJMD-I, several points form the basis of the RPJMD-I, including 1) creating a sound governance system, 2) developing an economy based on natural resources and local wisdom, 3) realizing the development of basic, social and economic infrastructure that is integrated and synergistic with the development of border areas as the homeland of the Republic of Indonesia, 4) improving the quality of human resources and cultural values of a community that is characteristic of a productive and harmonious society institution, and 5) maintaining environmental sustainability to support sustainable green economy development.

Table 2 shows some of the development focus carried out by the Mahakam Ulu based on the vision of the RPJMD-I of the Mahakam Ulu, where the development programs and activities become annual priorities programs realized by adjusting the allocation of the regional budget. The development activities program will run in the realization then be synergized with development programs at the central government, provincial governments, and the community and business world (Bappelitbangda 2018). From several years that have been running, it can be seen that from 2016 to 2020 the Mahakam Ulu government as a new autonomous region has focused its development on the basic needs of the community, such as improving service quality, acceleration of economic development, infrastructure development, and development of regional areas. It shows that the new autonomous region is a real effort to improve people's welfare, accelerate development, and improve access to quality public services (Moonti 2019, Sulistiowati 2014). The United Nations Development Programme (2011) also revealed that the presence of inclusive communities aims to form communities that can present access to all components of society to secure equal opportunities for all things in their social interactions. In order to realize all this, the Mahakam Ulu government must accelerate development (Table 2). 
Table 2.

Vision of the Mahakam Ulu RPJMD-I

\begin{tabular}{lcccccc}
\hline \multicolumn{7}{c}{ Building the Mahakam Ulu for all: Prosperous } \\
justice
\end{tabular}

Synergy Development programs or activities of the central government, provincial governments, districts or cities, non-governmental organizations, as well as from the business world

Source: Badan Pusat Statistik Kabupaten Kutai Barat (2019, 2020b)

Apart from that, in terms of realizing an inclusive society, several conditions of fulfilling development are needed first; as previously conveyed, such development includes the development of human resources, health, economic equality, and political participation of the community (Beckett 2009, Gea et al. 2016, Pelle \& Laczi 2015, Walker \& Musti-Rao 2016). The presence of a new autonomous region is the key to equitable development in the upstream area of the Mahakam River, although it sometimes is seen that new regional autonomy has poor development prospects (Simanjuntak 2015, Warsono \& Yuwanto 2016, Wismono et al. 2015). Nevertheless, in the Mahakam Ulu case, the new autonomous region responds to the hope of equitable development, which has long been aspired to by the upstream Mahakam River community.

Table 3.

Poverty line, number, and percentage of poor population in Mahakam Ulu

\begin{tabular}{lccc}
\hline Year & $\begin{array}{l}\text { Poverty line (IDR/ } \\
\text { capital/month) }\end{array}$ & $\begin{array}{l}\text { Total poor popu- } \\
\text { lation }\end{array}$ & $\begin{array}{l}\text { Percentage of the } \\
\text { poor population } \\
(\%)\end{array}$ \\
\hline 2015 & 44.981 & 2.83 & 10.50 \\
2016 & 490.563 & 2.88 & 10.65 \\
2017 & 534.502 & 3.07 & 11.29 \\
2018 & 566.944 & 3.15 & 11.62 \\
2019 & 588.786 & 3.19 & 11.25 \\
\hline
\end{tabular}

Source: Badan Pusat Statistik Kabupaten Kutai Barat (2019 \& 2020a)

Badrudin and Siregar (2015) revealed that the existence of regional autonomy could have a maximum effect on economic growth spending, but, ironically, it does not significantly affect people's welfare. It can be seen in Table 3, from the percentage of poor people in Mahakam Ulu in 2019, amounting to $11.25 \%$. Compared with 2017 and 2018, the poverty rate in 2019 has decreased compared to previous years. Table 3 show that the poverty rate from 2015 to 2019 experienced a fluctuating increase. The new autonomous regional government must realize prosperity for the people supported by proper economic development management. It is realized with development at the most basic level (Agustina 2019). 
Table 4 shows the number of schools in the Mahakam Ulu and the number of students who can go to school. It can also be seen that the number of schools in the Mahakam Ulu is 97. It considers sufficient if compared to the number of villages, 50 villages, and five sub-districts; however, the problem is that the number of schools is unevenly distributed in each sub-district and village several villages and subdistricts are constrained due to difficult distance, infrastructure, and geography. Therefore, the new autonomous regional government of Mahakam Ulu must make every effort to improve the accessibility of students to get proper education because guaranteed access to education is one of the requirements to realize an inclusive society (Beckett 2009, Darma \& Rusyidi 2015, Kadir 2015).

In the efforts of the regional government of Mahakam Ulu in fulfilling the achievement of the SDGs program to create an inclusive society, the implementation scheme is supported by the four pillars of social development, the environmental development pillar, the economic development pillar, and the pillar of legal development and governance (Kementerian Perencanaan Pembangunan Nasional 2020). Mahakam Ulu's government needs seriousness to develop the quality of human resources, which relates to the realm of social development pillars within the SDGs. Quality of education is a significant factor for advancing a region (Revida 2014, Astawa 2017).

Table 4.

Number of education facilities in Mahakam Ulu in 2019/2020

\begin{tabular}{lcccc}
\hline Type of Education & \multicolumn{2}{c}{ Schools } & \multicolumn{2}{c}{ Students } \\
\cline { 2 - 5 } & $\mathbf{2 0 1 8}$ & $\mathbf{2 0 1 9}$ & $\mathbf{2 0 1 8}$ & $\mathbf{2 0 1 9}$ \\
\hline Kindergarten & 31 & 34 & 1.049 & 1.031 \\
Elementary school & 39 & 39 & 4.206 & 4.168 \\
Middle school & 15 & 15 & 1.803 & 1.897 \\
High school & 6 & 7 & 1.070 & 1.137 \\
Vocational high school (SMK) & 2 & 2 & 172 & 186 \\
Total & $\mathbf{9 3}$ & $\mathbf{9 7}$ & $\mathbf{8 . 3 0 0}$ & $\mathbf{8 . 4 1 9}$ \\
\hline
\end{tabular}

Source: Badan Pusat Statistik Kabupaten Kutai Barat $(2019,2020 a)$

\section{The realization of development planning in Mahakam Ulu}

In the realm of political participation, which is also one of the requirements to create an inclusive society (Gea et al. 2016, Pelle \& Laczi 2015, Walker \& Musti-Rao 2016), Mahakam Ulu has increased the level of political participation in the Regional Head General Election or Pemilihan Kepala Daerah (Pilkada) in 2015 with the highest percentage of participation reaching $74.78 \%$ in East Kalimantan Province. The 2015 elections were the first elections for the Mahakam Ulu, and it was the starting point for the development steps under the leadership of the first definitive regent of the Mahakam Ulu. In the 2020 Regional Head General Election, which Mahakam Ulu just held, it still occupied the first position in the voter participation rate, with total participation reaching $75.41 \%$. Even though the implementation of the 2020 Regional Head General Election was carried out amid the Covid-19 pandemic, the voter participation rate was still high; this should be appreciated.

Mahakam Ulu's implementation in the 2020-2021 period has been running following the SDGs development pillars. This argument bases on processing the official Facebook social media account data of the Mahakam Ulu government (@pemkabmahakamulu); the data were collected using the NVivo 12 Plus Qualitative Data Software Analysis (QDSA). The Mahakam Ulu government account's amount of data through the NCapture tools is 231 posts with a total number of post-activity and account comments reaching 924 posts and comments.

The data obtained are then coded according to predetermined indicators guided by the four pillars of SDGs development; however, apart from the four indicators, we feel the need to add one other indicator, namely a health development indicator. Health development indicators are one of the important things 
facing the Covid-19 pandemic in the Mahakam Ulu. Furthermore, data reduction is carried out in the data coding process to classify the Facebook account data according to predetermined variable categories. Figure 3 shows the final results of data processing; these data show that development in law and governance in 2020 is the activity most often carried out by the Mahakam Ulu government with a score of $32.81 \%$. Meanwhile, in the first semester of the ongoing 2021 period, it was found that the development attention carried out by the Mahakam Ulu government was on the health development side with a score of $62.50 \%$.

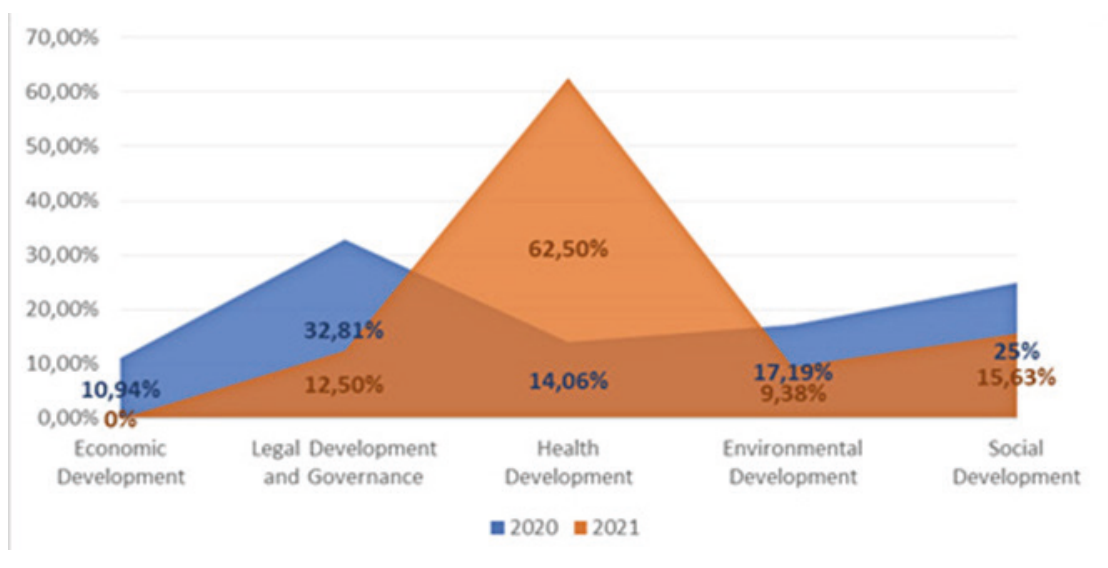

Figure 3.

Implementation of development planning in Mahakam Ulu

Source: Primary research data

As a new autonomous region, Mahakam Ulu regional government's efforts to realize an inclusive society have been seen in its issued programs. The implementation is constrained by the availability of necessary infrastructure, which is minimal, limited budget resources, and the quality of human resources, which is illustrated through the capacity of the public service apparatus that still feels not optimal in carrying out the planned policies. The seriousness and alignments of local governments Mahakam Ulu have seen in the vision of the RPJMD-I, which, if we look at the formulation and implementation of its programs, has adjusted to the fulfillment of the four pillars of SDGs (Fukuda- Parr 2016, Kementerian Perencanaan Pembangunan Nasional 2020). The new regional autonomy can improve community welfare, accelerate development, and improve access to quality public services, ultimately creating inclusive communities in Mahakam Ulu (Moonti 2019, Sulistiowati 2014).

Nevertheless, it is necessary to underline that all kinds of program innovation efforts undertaken by the Mahakam Ulu government to reach an inclusive society must always be based on the principle of SDGs. SDGs contain a variety of interactions that are interconnected between one goal and another to achieve them. Indeed, as stated in the RPJMD-I of the Mahakam Ulu, it is necessary to pay attention to the various interrelated things, lest innovation for the inclusive community being aimed at actually makes us forget about other fundamental things that must also be achieved (Le Blanc 2015, Purnomo et al. 2018). Prabowo (2019) has reminded us that the implementation of regional autonomy must be accompanied by a firm development policy and supervision so that the effectiveness of regional development can maximally be achieved and following the aspirations aspired.

\section{Conclusion}

Mahakam Ulu District is a newly established autonomous region in East Kalimantan Province, with the Ujoh Bilang being its capital. To create an inclusive community, the Mahakam Ulu has sought to include it in the Mahakam Ulu District Long Term Development Plan (RPJPD) for 2016-2025, which was then revealed in 2016-2021 Regional Medium Term Development Plan I (RPJMD-I). The new autonomous region is an answer rather than an effort to bring an inclusive community upstream in the Mahakam River, namely the Mahakam Ulu. 
The Mahakam Ulu establishment provides a breath of fresh air for the development ideals desired by the Mahakam River upstream community, which has long wanted equitable development and fulfillment of their fundamental rights, which were sometimes overlooked before by the provincial districts governments. With the RPJMD-I of the Mahakam Ulu, the development movement can be focused and directly touch the regions' community. Development planning has also been high for achieving the SDGs; it can be seen from the programs that have been carried out, aiming to bring the Mahakam Ulu prosperity and justice. The transformation of the values contained in the pillars of the SDGs has also been present in the annual priority programs that have been carried out by the Mahakam Ulu, including in terms of social development, environmental development, economic development, and legal and governance development, which are seen to be continued to be pursued by all parties upstream of the Mahakam River, Mahakam Ulu.

It is necessary to design a development plan strategy to answer the time's challenges to realize an inclusive society. Looking at the global and national situation, we suggest that Mahakam Ulu needs to design an RPJMD-II that always puts forward the prospects of sustainable development in the fields of infrastructure, economy, environment, and health, as well as improving the quality of life of the community, both in terms of morality and academia. It is important because a new autonomous region of development with a clear end goal is needed. All superior resources in the Mahakam Ulu can focus on creating an inclusive society that can ultimately bring Mahakam Ulu prosperity and justice.

\section{References}

Agustina E (2019) The role of community empowerment carried out by village government in the regional autonomy era. Unifikasi: Jurnal Ilmu Hukum 6 (1):34-39.

Aisyah, Dharmadi, Nasution SH, Oktaviani D, \& Hartoto DI (2008) Kondisi kualitas air habitat Pesut Mahakam (Orcaella brevirostris) di wilayah Daerah Aliran Sungai Mahakam, Kalimantan Timur. Jurnal Penelitian Perikanan Indonesia 14 (1):47-53.

Akbar S (2018) Analisa masalah-masalah yang muncul dalam pemekaran wilayah baru pada penyelengara otonomi daerah. Jiaganis: Jurnal Ilmu Administrasi Negara \& Bisnis 3 (1):1-15.

Ariastuti R \& Herawati VD (2016) Optimalisasi peran sekolah inklusi. Jurnal Pengabdian pada Masyarakat 1 (1):38-47. https://doi.org/10.30653/002.201611.7.

Astawa INT (2017) Memahami peran masyarakat dan pemerintah dalam kemajuan mutu pendidikan di Indonesia. Jurnal Penjaminan Mutu 3 (2):197-205. https://doi.org/10.25078/jpm.v3i2.200.

Badan Pusat Statistik Kabupaten Kutai Barat (2017) Indikator kesejahteraan rakyat Kabupaten Mahakam Ulu. [Accessed 4 April 2021]. https://mahulukab.bps.go.id/publication/2018/12/11/ ed5bd40b1c82b41426f402f9/indikator-kesejahteraan-rakyat-kabupaten-mahakam-ulu-2017. html.

Badan Pusat Statistik Kabupaten Kutai Barat (2019) Statistik daerah Kabupaten Mahakam Ulu 2019. Kutai Barat: Badan Pusat Statistik Kabupaten Kutai Barat. [Accessed 4 April 2021]. https:// mahulukab.bps.go.id/publication/2019/11/01/6442437c7ccc7d13e08563e8/statistik-daerahkabupaten-mahakam-ulu-2019.html.

Badan Pusat Statistik Kabupaten Kutai Barat (2020a) Kabupaten Mahakam Ulu dalam angka 2020. Kutai Barat: Badan Pusat Statistik Kabupaten Kutai Barat. [Accessed 4 April 2021]. https://mahulukab. bps.go.id/publication/2020/04/27/cb97e59fc20ad1 dab4246a65/kabupaten-mahakam-huludalam-angka-2020.html.

Badan Pusat Statistik Kabupaten Kutai Barat (2020b) Statistik daerah Kabupaten Mahakam Ulu 2020. Kutai Barat: Badan Pusat Statistik Kabupaten Kutai Barat. [Accessed 4 April 2021]. https:// mahulukab.bps.go.id/publication/2020/08/14/64df0c70c2407ac641b31d6b/statistik-daerahkabupaten-mahakam-ulu-2020.html.

Badrudin R \& Siregar B (2015) The evaluation of the implementation of regional autonomy in Indonesia. Ejem: Economic Journal of Emerging Markets 7 (1):1-11. https://doi.org/10.20885/ejem.vol7. iss 1.art1. 
Bappelitbangda (2018) Paparan Kepala Bappelitbangda. [Accessed 4 April 2021]. https://www. bappelitbangda.mahakamulukab.go.id/berita?page $=11$.

Beckett AE (2009) Challenging disabling attitudes, building an inclusive society: Considering the role of education in encouraging non-disabled children to develop positive attitudes towards disabled people. British Journal of Sociology of Education 30 (3):317-329. https://doi. org/10.1080/01425690902812596.

Brandão C (2015) P. Bazeley and K. Jackson, qualitative data analysis with NVivo (2 $2^{\text {nd }}$ ed.). Qualitative Research in Psychology 12 (4):492-494. https://doi.org/10.1080/14780887.2014.992750.

Darlen MF, Hadi S, \& Ardiansyah M (2015) Pengembangan wilayah berbasis potensi unggulan di Kabupaten Manggarai Timur Provinsi NTT sebagai daerah otonomi baru. Tata Loka 17 (1):37-52.

Darma IP \& Rusyidi B (2015) Pelaksanaan sekolah inklusi di Indonesia. Prosiding Penelitian dan Pengabdian Kepada Masyarakat 2 (2):223-227. https://doi.org/10.24198/jppm.v2i2.13530.

Dishub Kutai Kartanegara (2021) Kondisi geografis dan iklim Kutai Kartanegara. [Accessed 4 April 2021]. https://dishub.kukarkab.go.id/pages/kondisi-geografis-dan-iklim-kutai-kartanegara.

Fithriana A \& Annissa J (2016) Perbandingan kualitas demokrasi dalam perspektif kesetaraan gender antara Indonesia dan Thailand. Sawala: Jurnal Administrasi Negara 4 (2):12-25. https://doi. org/10.21009/jimd.v16i2.8753.

Fukuda-Parr S (2016) From the millennium development goals to the sustainable development goals: Shifts in purpose, concept, and politics of global goal setting for development. Gender and Development 24 (1):43-52. https://doi.org/10.1080/13552074.2016.1145895.

Gea M, Alaman X, Rodriguez P, \& Martinez V (2016) Towards smart \& inclusive society: Building 3D immersive museum by children with cognitive disabilities. In: $8^{\text {th }}$ International Conference on Education and New Learning Technologies, 4-6 July, Barcelona.

Pemerintah Provinsi Kalimantan Timur (2013) Kabupaten Mahakam Ulu hadiah bagi masyarakat Kalimantan Timur. [Accessed 26 May 2020]. https://kaltimprov.go.id/berita/kabupaten-mahakamulu- hadiah-bagi-masyarakat-kaltim.

Indonesia Kaya (2019) Sungai Mahakam. [Accessed 30 May 2020]. https://www.indonesiakaya.com/ jelajah- indonesia/detail/sungai-mahakam.

Indonesia-info.net (2021) Sungai Mahakam. [Accessed 4 April 2021]. http://p2k.itbu.ac.id/ind/30642950/Sungai-Mahakam_29911_itbu_sungai-mahakam-itbu.html.

Jati W (2012) Inkonsistensi paradigma otonomi daerah di Indonesia: Dilema sentralisasi atau desentralisasi. Jurnal Konstitusi 9 (4):743-770.

Kadaryanto B (2017) Implikasi pembentukan daerah persiapan otonomi baru dalam bingkai Negara Kesatuan Republik Indonesia untuk peningkatan kesejahteraan rakyat berdasarkan UndangUndang Nomor 23 Tahun 2014 tentang pemerintahan daerah. Aktualita: Jurnal Hukum 17 (1):7586. https://doi.org/10.29313/aktualita.v1i2.3998.

Kadir A (2015) Penyelenggaraan sekolah inklusi di Indonesia. Jurnal Pendidikan Agama Islam 3 (1):122. https://doi.org/10.15642/jpai.2015.3.1.1-22.

Kaefer F, Roper J, \& Sinha P (2015) A software-assisted qualitative content analysis of news articles: Example and reflections. Forum Qualitative Sozialforschung 16 (2). https://doi.org/10.17169/ fqs-16.2.2123.

Kementerian Perencanaan Pembangunan Nasional (2020) Empat pilar SDGs. [Accessed 8 April 2020]. https://sdgs.bappenas.go.id/.

Le Blanc D (2015) Towards integration at last? The sustainable development goals as a network of targets. Sustainable Development 23 (3):176-187. https://doi.org/10.1002/sd.1582.

Maftuhin A (2017) Mendefinisikan kota inklusif: Asal-usul, teori dan indikator. Tataloka 19 (2):93. https://doi.org/10.14710/tataloka.19.2.93-103.

Mi'rojul (2017) Analisis konflik dalam industri migas (studi kasus konflik masyarakat dan PT. Energi Mineral Langgeng di Desa Tanjung Kab. Sumenep. Thesis, Universitas Airlangga, Surabaya.

Miles MB \& Huberman AM (2009) Manajemen Data dan Metode Analisis. In: Denzin NK \& Lincoln YS (ed). Handbook of Qualitative Research. Yogyakarta: Pustaka Pelajar.

Moleong LJ (2007) Metodologi Penelitian Kualitatif (Edisi Revisi). Bandung: PT. Remaja Rosdakarya. 
Moonti RM (2019) Regional autonomy in realizing good governance. Substantive Justice International Journal of Law 2 (1):43-53. https://doi.org/10.33096/substantivejustice.v2i1.31.

Muqoyyidin AW (2013) Pemekaran wilayah dan otonomi daerah pasca reformasi di Indonesia: Konsep, fakta empiris dan rekomendasi ke depan. Jurnal Konstitusi 10 (2):287-310.

Pelle A \& Laczi R (2015) Inclusive society as a necessary condition for knowledge-based competitiveness in the European Union. Managing Global Transitions 13 (4):355-367.

Peta Tematik Indonesia (2014) Administrasi Kabupaten Mahakam Ulu. [Accessed 7 April 2020]. https:// petatematikindo.wordpress.com/2014/04/07/administrasi-kabupaten-mahakam-ulu/.

Posumah F (2015) Pengaruh pembangunan infrastruktur terhadap investasi di Kabupaten Minahasa Tenggara. Jurnal Berkala Ilmiah Efisien 15 (2):1-13.

Prabowo H (2019) Influence of implementation of development and supervision policy to the effectiveness of regional autonomy in Indonesia. Jurnal Bina Praja 21:63-73. https://doi. org/10.21787/jbp.11.2019.63-73.

Purnamasari SA (2015) Persepsi masyarakat terhadap kualitas pelayanan kesehatan sebelum dan setelah pemekaran Kota Tangerang Selatan. Journal of Politic and Government Studies 4 (3):31-40.

Purnomo EP, Anand PB, \& Choi JW (2018) The complexity and consequences of the policy implementation dealing with sustainable ideas. Journal of Sustainable Forestry 37 (3):270-285. https://doi.org/10.1080/10549811.2017.1406373.

Purwaningsih T (2015) Politik kekerabatan dalam politik lokal di Sulawesi Selatan pada era reformasi (Studi tentang rekrutmen politik pada Partai Golkar, Partai Amanat Nasional dan Partai Demokrat Sulawesi Selatan Tahun 2009). Dissertation, Universitas Muhammadiyah Yogyakarta, Yogyakarta.

Revida E (2014) Strategi peningkatan daya saing pendidikan di era globalisasi dan otonomi daerah. Jurnal Transformasi Administrasi 4 (1):700-709.

Simanjuntak K (2015) Implementasi kebijakan desentralisasi pemerintahan di Indonesia. Jurnal Bina Praja 7 (2):111-130. https://doi.org/10.21787/jbp.07.2015.111-130.

Sugino T(2010)Evaluating agricultural policies oflocal governments in Indonesiaafter the implementation of regional autonomy by principal component analysis. Journal of Development and Agricultural Economics 2 (10):359-367. https://doi.org/10.24198/sosiohumaniora.v16i3.5767.

Sulistiowati R (2014) Implementasi desentralisasi dan otonomi daerah pada Daerah Otonomi Baru (DOB) (Studi di Kabupaten Pesawaran dan Kabupaten Pringsewu Provinsi Lampung). Sosiohumaniora: Journal of Social Sciences and Humanities 16 (3):270-281.

United Nations Development Programme (2011) Beyond transition towards inclusive societies. [Accessed 4 April 2021]. https://www.undp.org/content/undp/en/home/librarypage/democraticgovernance/Beyond-Transition-Inclusive-Societies.html.

Walker Z \& Musti-Rao S (2016) Inclusion in high-achieving Singapore: Challenges of building an inclusive society in policy and practice. Global Education Review 3 (3):28-42.

Warsono H \& Yuwanto (2016) Improving public welfare or burdening the state: Indonesia's new autonomous region in decentralization era. In: 2016 International Conference on Public Management (ICPM 2016), Kumming, 15-17 July.

Wenda WL \& Akib H (2015) Pembangunan ekonomi dalam era otonomi daerah di Kabupaten Pegunungan Bintang, Indonesia. Jurnal Ilmiah Ilmu Administrasi Publik 5 (1):43-51.

Wismono FH, Ramdhani LE, \& Rustan A (2015) Penataan kelembagaan pada Daerah Otonom Baru (DOB) (Studi kasus di Provinsi Kalimantan Utara). Jurnal Borneo Administrator 11 (3):362-381.

Yakub A, Ghani ABA, \& Anwar MS (2018) Urgency of political decentralization and regional autonomy in Indonesia: Local perspectives. Journal of International Studies 14:141-150.

Yuniza ME (2014) Pengaturan pelayanan kesehatan di Kota Yogyakarta setelah penerapan otonomi luas. Mimbar Hukum 25 (3):377-387.

Zhao X \& Zhang C (2018) From isolated fence to inclusive society: The transformational disability policy in China. Disability and Society 33 (1):132-137. 